\title{
Impact of Firm Leverage to Performance: Evidence from Shariah and Non-Shariah Compliant Companies in Malaysia
}

\author{
Wan Shahzlinda Shah Bt Shahar ${ }^{\mathrm{a}, 1}$, Wan Shahdila Shah Bt Shahar ${ }^{\mathrm{b}, 2}$ \\ ${ }^{a}$ Faculty of Economic and Management, University College Bestari, Malaysia \\ ${ }^{\mathrm{b}}$ Department of Banking and Finance, Faculty of Management \& Muamalah, Kolej Universiti Islam Antarabangsa \\ Selangor, Malaysia \\ 11lyndashahz@gmail.com,2shahdila@kuis.edu.my
}

\begin{abstract}
This study are meant to investigates the impact firm leverage towards the performance of Shariah compliant listed companies with the non-compliant Shariah listed companies and to discover on their firm leverage practices from each other. A total 70 construction companies listed in Securities Commission Malaysia (SC) main board belonging to construction sector for Shariah and non-Shariah compliant listed companies are analyzed covering the period from 2008 until 2012. Using pooled ordinary least square (POLS) method and generalized least square (GLS) with random and fixed effects, the results clearly indicated that firm leverage's choice between Shariah and non-Shariah compliant companies are totally difference. It shows that debt ratio does not give an impact towards Shariah compliant company's performance based on return in asset (ROA) and return on equity (ROE) but short-term debt and long-term debt does give an impact to Shariah compliant company's performance based on Marketto-book value (MTBV) with negative relationship. On the other hand, in Non-Shariah Compliance Company, inverse result shows when long-term debt and total debt does give an impact to Non-Shariah compliant company's performance based on ROE. While, size also represent a positive relationship toward N0n-Shariah compliant company's performance
\end{abstract}

Keywords: Firm leverage, Debt Ratio, Short Term Debt, Long Term Debt, Return on Asset, Return on Equity, Market to Book Value.

\section{Introduction}

The Islamic finance and economic system has existed since the time of the Prophet Muhammad SAW. However, during the time, the economic activity of buying and selling, and savings and loans activities were not as broad as now. Nevertheless, the principle of the Islamic trade and finance are still remains the same.

In Malaysia, the financial and real sectors of Shariah compliant and non-compliant are running side by side by side. However, Shariah compliant company are much differ to the Non-Shariah Compliant in sense of the fundamental and value of Islamic principle which they are deemed to obey. In order for a company to be listed as the Shariah-compliant, one must follow all the criteria and the benchmark set by the Bank Negara Malaysia (BNM), Shariah Advisory council (SAC) and Securities Commission Malaysia (SC).

In this modern contemporary financial management, various essential business decisions concerning financing and project required the big sum of capital is needed. Capital structure is all about how firm find their source of financing which are either by debt or by equity. Therefore, critical business and investment decision is crucial to boost the firm's performance. Nevertheless, the firm's business activities must not violates with what is prohibited in Islam. It supported by (Jais, 2013) whereby the most important strategic financial decisions is capital structure and arrangement of diverse sources of funds leads to different implication on the firm's performance and shareholder's wealth.

In a way, the value of the firm will maximize with assortment of debt and equity securities in capital structure management. The analysis of the correlation between capital structure and firm's performance is very crucial (Kinsman and Newman, 1999). The expansion of capital structure theory began from Modigliani and Miller Theorem, followed by Trade-Off Theory, Signaling Approach, Pecking Order Theory, and Agency Theory. However according to Ebaid (2009) and Al-Dohaiman (2008) the capital structure could be best explained in terms of two dominant theories which is the trade-off and pecking order theories.

\section{STATEMENT OF THE PROBLEMS}

Malaysia has a unique financial system that comprising two entities which Shariah compliant company and Non-Shariah compliant company that operating side by side. The natures of Shariah compliant companies are differ from the Non-Shariah compliant company. However, Shariah compliant companies are deemed to comply with the Shariah values, rules and restriction in dealing with their financial sources and financing to boost their performance. In the context of Shariah principles, Shariah compliant company is not allowed to involve in any prohibited element.

Particularly, just like any normal company, Shariah compliant company also deals with corporate finance in making decision on their source of financing or normally known as capital structure. Capital structure refers to the mix of equity and debts maintained by firm, hence it is also reflects to a firm's financial liabilities with debt securities holders and equity securities holders representing the two different classes of investors of the firm. Basically, the nature of firm's objective whether to maximize firm's value or the shareholder' value.

Ogebe (2013) mentioned that firms will normally facing problems when structuring their capital and planning 
for their source of financing, whether to raise debt or equity capital in order to determine its implication towards the firm's performance, as it is crucial for firm's value and its survival.

Therefore, there are many issues arise by the society which is Shariah compliant companies operation are alike to conventional counterpart. Moreover, many existing literature focuses on the impact of capital structure to performance, considering the determinant of capital structure in Non-Shariah compliant companies (Tian, 2007; AlDohaimin, 2008; Ahmad, 2012; Muritala, 2012 and Rahim, 2013). However, little attention is drawn to the impact of firm leverage toward Shariah Compliance companies and Non-Shariah compliant companies. Since the business nature of compliance company are differ to the Non-Shariah compliance company, therefore there is no evidence about how Islamic firm leverage will impacts upon financial performance and corporate value in markets since Islamic debt also affected companies performance as indicated by market-based and accounting-based measures. Therefore, the study on this area is important and this issue will be explored in this study. From the foregoing, therefore it is significant to value on how firm leverage decision could affect their performance and how firm leverage practices of the Shariah compliant company differ from the Non-Shariah compliant company.

\section{OBJECTIVE OF THE RESEARCH}

The study has several objectives. First is to identify how firm leverage would influence the firm performance of Shariah-compliant companies with Non-Shariah compliant companies. The second objective of this paper is intended to compare if the firm leverage practices between Shariahcompliant listed companies with non-Shariah compliant listed companies differ from each other.

\section{THEORETICAL FRAMEWORK}

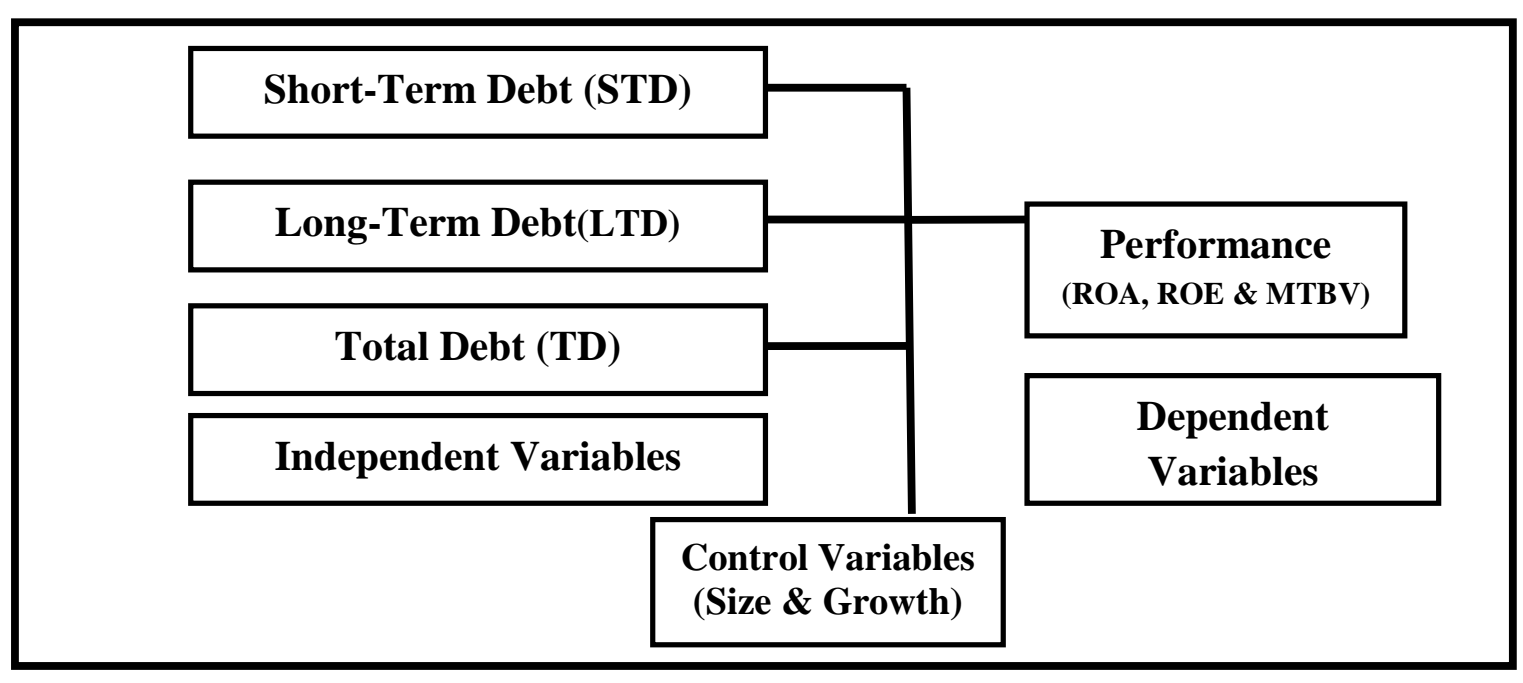

Figure 1: Framework of Study

\section{LITERATURE REVIEW}

\section{Islamic Capital Structure in Light of Maqasid Shariah}

Many researchers have investigated the relationship between debt issues and shareholders' wealth, but there are lack of studies, which examine its impact toward performance in Shariah compliant companies. It provided that Shariah compliant company must comply with the Activity-Based Benchmark set by Central Bank of Malaysia. In Islam, Allah SWT has given a parameter, which it is permitted in dealing with equity, and debt as long as it fulfill the Maqasid Shariah. However, according to Asim (2010) in his study, he is comparing debt with equity in the context of Maqasid Shariah and from the research, it is concluded that debt has the potential of harming the Maqasid Shariah which is the perseverance of religion, life, intellect, lineage and property. Besides, debt can leave the business vulnerable during hard time when sale drop. According to Fitriya (2012) through her study on impact of Islamic debt on firm performance in Malaysia and Indonesia, prove that companies issuing Islamic debt as the capital structure or source of financing are having higher firm value and have a positive and significant impact on shareholders' wealth. There is another alternative for debt in Islamic capital structure, which is Islamic instrument such as sukuk. Naturally, Islamic capital structure by using Islamic debt can reduces the agency problem within the company and hence increases firm value (Fitriya, 2012). Even though, Sukuk is proven more resilient but Islamic debt also affected firm performance as indicated by market-based and accountingbased measures, therefore, the study on these perspectives are important and worth to explore.

\section{Performance}

Various literatures apply numbers of different measures of firm's performance. These measures include accounting-based measures as Ebaid (2009) applies on ROE, ROA, and GM to measure performance. Another technique is market-based measures such as stock returns, Tobin Q, market-to-book value (MTBV) and volatility, which use by 
Welch (2004), Ebaid (2009) and many other researchers. Ogebe (2013) stated that performance of firms could also be measure by using profitability and efficiency ratio, which is return on equity (ROE), return on investment (ROI), asset turnover, and operating expenses ratio.

However, this study uses two of common accounting-based performance measures which is ROE was the ratio of net profit to average total equity, while ROA was computed by the ratio of net profit to average total assets and one market based performance measure which is market-to-book value.

\section{Leverage}

Based on Patrick Ogebe (2013) study on the impact of capital structure on firms' performance in Nigeria, it shows that leverage has a negative and statistically significant relationship with firm performance and firms should use more of equity than debt in financing their business activities. This result is supported by Chen et. al ( 2008) and Kyereboah-Coleman (2007) which analyze on the connection between capital structure and performance of microfinance institutions in sub-Saharan Africa viewing that high leverage is certainly associated with performance.

\section{Size}

Previous researches also consider firm size when examining whether large companies and small and medium size companies would behave differently. The results are mixed and inconclusive and stress the importance of further empirical study. Prior researches recommend that company's size may influence its performance; Yadav (2012) proposed that larger companies may have a better variety of abilities and can enjoy economies of scale, which may influence the results and the inferences. This is parallel with the study done by Jermias (2008). While smaller companies would prefer for internal financing over external debt financing, as the cost of external financing is higher for the companies (Abor\&Biekpe, 2009).

Muritala (2012) also agree that the size of a company is measured as a vital determinant of company's profitability. According to Wang (2013), Mohammed S Al-
Dohaiman (2008) and Rahim (2013), company's size is positively significant related to performance measures. The positive relationship between firm size and performance is consistent with the predictions of the trade-off theory suggest that larger firms tend to borrow more due to their ability to diversify the risk. Besides, Rajan (1995) also found that leverage is positively correlated to company size which study found larger firms in Germany tend to have less debt rather than to small size firms.

It seems there is an accord between theories on the positive outcome of size on firm's capital structure even though their justification may be differs. However, Ebaid (2009) argues that size has negatively significant relationship with performance.

\section{Growth}

This is relevant with the previous literatures which firm with high growth rate have a high debt (Tian, 2007), bank willing to lend money to companies who has good growth rate (Myers, 1984 and Rahim 2013). This is similar to the finding made by Barclay (1995) in which the large and low growth rate's companies tend to issue more long term debt as they are less risky and can make a greater use of the long term debt. However, Pecking-order hypothesis suggest a negative relationship between leverage and growth opportunity. On the other hand, Myers (1977) argues that agency problems can be alleviated as the firm issues short term debt rather than long term debt. Therefore, this would suggest that there is a negative relationship between growth with long term debt and a positive relationship with short term debt.

\section{RESEARCH METHODOLOGY Data}

The sample population of this study is Malaysia construction sector which consist of 35 Shariah compliant and 35 nonShariah compliant listed in Bursa Malaysia during 2008 and 2012.

The proxies use for the dependent variables and explanatory variables are displayed in Table 1 .

Table 1: Proxies for Dependent and Independent Variables Studied

\begin{tabular}{|l|l|}
\hline Dependent variables & Proxies \\
\hline Return On Asset (ROA) & Net Profit / Total Asset \\
\hline Return On Equity (ROE) & Net Profit / Total Equity \\
\hline Market- To-Book-Value (MTBV) & Market Capitalization / Total Asset \\
\hline Independent Variables & Proxies \\
\hline Short Term Debt (STD) & Short Term Debt (STD) / Total Asset \\
\hline Long Term Debt (LTD) & Long Term Debt (LTD) / Total Asset \\
\hline Total Debt (TD) & Total Debt (TD) / Total Asset \\
\hline Control Variable & Proxies \\
\hline Size & Logarithm of Sales \\
\hline Growth & Total Asset \\
\hline
\end{tabular}




\section{Statistical Methods}

Data analysis involves sixth steps in this research. The first step is to construct Model adequacy checking Second step reliability test third, descriptive analysis fourth, Unit Root Test to test the stationary data. Fifth, is to run the descriptive statistical analysis. The sixth step was using three panels of econometrics techniques, which are pooled ordinary least square (Regression Analysis), random effects, fixed effects, and the HausmanTest were used to estimate the relationship between capital structure and firm performance. This study used the combination of SPSS, E-views and Stata to run the data sets.

\section{Model Specification}

The relationship between leverage and a firm $s$ performance was tested by the following regression models:

\section{Model 1}

Model 2

$$
\operatorname{PERFORMANCE}(S C)_{i, t}=\beta_{0}+\beta_{1} L_{T} S_{i, t}+\beta_{2} \operatorname{logSIZE_{i,t}}+\beta_{2} G R O W T H_{i, t}+\varepsilon_{i, t}
$$

\section{Model 3}

$$
\text { PERFORMANCE }(S C)_{i, t}=\beta_{0}+\beta_{1} L T D_{i, t}+\beta_{2} \operatorname{logSIZE_{i,t}}+\beta_{2} G_{R O W T H}+\varepsilon_{i, t}
$$

Model 4

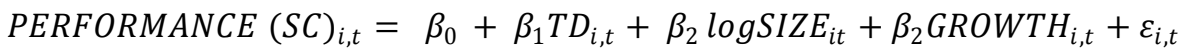

\section{Model 5}

$$
\text { PERFORMANCE }(N S)_{i, t}=\beta_{0}+\beta_{1} L_{T S} S_{i, t}+\beta_{2} \operatorname{logSIZE_{i,t}}+\beta_{2} \text { GROWTH }_{i, t}+\varepsilon_{i, t}
$$

Model 6

$$
\text { PERFORMANCE }(N S)_{i, t}=\beta_{0}+\beta_{1} L_{T} D_{i, t}+\beta_{2} \operatorname{logSIZE_{i,t}}+\beta_{2} \text { GROWTH }_{i, t}+\varepsilon_{i, t}
$$

$$
\text { PERFORMANCE }(N S)_{i, t}=\beta_{0}+\beta_{1} \text { TD }_{i, t}+\beta_{2} \operatorname{logSIZE_{i,t}}+\beta_{2} \text { GROWTH }_{i, t}+\varepsilon_{i, t}
$$

\section{RESULT}

\begin{tabular}{|c|c|c|}
\hline \multicolumn{3}{|c|}{ Shariah Compliant Listed Companies } \\
\hline \multirow{2}{*}{ Mean } & Equity Ratio & 35.0897 \\
\cline { 2 - 3 } & Debt Ratio & 10.6388 \\
\hline \multicolumn{3}{|c|}{ Non-Shariah Compliant Listed Companies } \\
\hline \multirow{2}{*}{ Mean } & Equity Ratio & 33.2899 \\
\cline { 2 - 3 } & Debt Ratio & 23.7686 \\
\hline
\end{tabular}

\section{Descriptive Statistics}

Table 2: Descriptive statistic of the variables

\begin{tabular}{|l|l|l|l|l|l|l|l|l|}
\hline \multicolumn{9}{|l|}{ Shariah Compliant Listed Companies } \\
\hline Stats & ROA & ROE & MTBV & STD & LTD & TD & SIZE & GROWTH \\
\hline Mean & 0.5234 & 0.8546 & -0.0684 & -0.3631 & -1.4482 & -0.2781 & 5.5295 & -0.9482 \\
\hline Min & -1.3010 & -0.5850 & -2.4229 & -1.0486 & -4.4730 & -0.6856 & 3.2148 & -2.3979 \\
\hline Max & 2.7738 & 2.7450 & 2.1229 & 1.0136 & 0.5906 & 1.0728 & 6.6690 & 0.4609 \\
\hline Variance & 0.3611 & 0.2900 & 0.4957 & 0.0852 & 0.6777 & 0.0480 & 0.3290 & 0.2468 \\
\hline Std. dev & 0.6009 & 0.5385 & 0.7041 & 0.2919 & 0.8232 & 0.2192 & 0.5736 & 0.4968 \\
\hline Non-Shariah Compliant Listed Companies & \multicolumn{1}{|l}{} & & & \\
\hline Mean & 0.5391 & 0.8958 & 0.0732 & -0.5852 & -0.9502 & -0.3263 & 5.3903 & -1.0267 \\
\hline Min & -1.0458 & -0.2366 & -2.3122 & -2.5997 & -3.2544 & -2.5997 & 2.7917 & -3.2218 \\
\hline Max & 1.5907 & 2.1021 & 2.4872 & 0.2004 & -0.0845 & 0.2004 & 7.3053 & -0.0088 \\
\hline Variance & 0.1719 & 0.1548 & 0.6531 & 0.1177 & 0.3151 & 0.0760 & 0.3871 & 0.2846 \\
\hline Std. dev & 0.4145 & 0.3935 & 0.8081 & 0.3430 & 0.5613 & 0.2758 & 0.6221 & 0.5334 \\
\hline
\end{tabular}


Table 2 describes the statistics of both the dependent and independent variables in the sample of this study. On average, ROA in Shariah compliant and nonShariah compliant companies are almost the same which is $52.34 \%$ and $53.91 \%$. Same goes to ROE, there are seem slightly different between Shariah compliant and nonShariah compliant listed companies which is $85.46 \%$ and $89.58 \%$ respectively. The mean value for MTBV in Shariah compliant listed companies is -0.0684 while Non-Shariah compliant companies mean value for MTBV indicates of 0.0732 respectively, suggesting that most of the companies in this sample experienced low firm performance based on the market measure. The mean value for STD in Shariah compliant listed companies is 0.3631 which is low as compared to Non-Shariah compliant companies at 0.5852 . This may be due to the fact that Shariah compliance company are not encourage to involve in debt trading and as Activity Based-Benchmark set by Central Bank of Malaysia. The mean value for LTD in Shariah compliant listed companies at 1.4482 more than non-Shariah compliant companies at 0.9502 indicating that most of the Shariah compliant companies depends more on LTD as one of their sources of funds. However, non-shariah compliant indicates high TD at 0.3263 as compared to shariah complaint companies at 0.2781 . Size is seem slightly difference where Shariah compliant companies at 5.5295 whereas non-shariah compliant at 5.3903. These results points out that both Shariah and Non-Shariah compliant listed companies in this sample mostly are of the firms are big companies. Sale also indicate almost the same where Shariah compliant companies at 0.9482 whereas non-shariah compliant at 1.0267 .

\section{Correlation}

Correlation analysis is used to describe the strength and direction of the linear relationship between variables. The sign out at the front indicates whether there is a positive correlation or negative correlation. The size of the value by ignoring the sign provides an indication of the strength of the relationship among variables.

Table 3: Correlation

\begin{tabular}{|c|c|c|c|c|c|c|c|c|}
\hline \multicolumn{9}{|c|}{ Shariah Compliant Listed Companies } \\
\hline & ROA & ROE & MTBV & STD & LTD & TD & SIZE & GROWTH \\
\hline ROA & 1.0000 & & & & & & & \\
\hline ROE & 0.9433 & 1.0000 & & & & & & \\
\hline MTBV & 0.1407 & 0.0486 & 1.0000 & & & & & \\
\hline STD & -0.1247 & 0.0966 & -0.2735 & 1.0000 & & & & \\
\hline LTD & 0.0132 & 0.1420 & -0.3033 & -0.1599 & 1.0000 & & & \\
\hline TD & -0.1384 & 0.1516 & -0.2884 & 0.8000 & 0.3758 & 1.0000 & & \\
\hline SIZE & -0.1918 & -0.0519 & 0.0198 & -0.0629 & 0.5582 & 0.3411 & 1.0000 & \\
\hline GROWTH & 0.0453 & 0.0481 & 0.0484 & 0.1504 & -0.2249 & 0.0428 & -0.2690 & 1.0000 \\
\hline \multicolumn{9}{|c|}{ Non-Shariah Compliant Listed Companies } \\
\hline & ROA & ROE & MTBV & STD & LTD & TD & SIZE & GROWTH \\
\hline ROA & 1.0000 & & & & & & & \\
\hline ROE & 0.7381 & 1.0000 & & & & & & \\
\hline MTBV & 0.0201 & 0.0509 & 1.0000 & & & & & \\
\hline STD & -0.0484 & -0.0050 & -0.0242 & 1.0000 & & & & \\
\hline LTD & -0.2144 & -0.0604 & -0.0400 & -0.4659 & 1.0000 & & & \\
\hline TD & -0.3116 & 0.2018 & -0.0031 & 0.2911 & 0.4411 & 1.0000 & & \\
\hline SIZE & -0.0185 & 0.2553 & -0.0004 & 0.1237 & 0.1469 & 0.4216 & 1.0000 & \\
\hline GROWTH & 0.2221 & 0.0040 & -0.1391 & 0.2533 & -0.0984 & -0.1876 & -0.1495 & 1.0000 \\
\hline
\end{tabular}

Based on the table 3, dependent variables ROA and ROE for both data sets have a multicollinearity problems since the correlation result between the variables present more than 0.7. Besides, STD and TD in Shariah compliant companies also indicate that there is multicollinearity problem. Even though there is multicorrelation problem in the model which due to the capital structure measured by the three related variables, STD, LTD and TD are used as a single independent variable in the relationship. However, this is necessary in order to see the impact of debt on the firm's performance and this research is worth to explore. Like most previous study (Chen et. al, 2008; Ebaid, 2009; Wang, 2011; Yadav, 2012) has also the same independent variables to in order to investigate the impact capital structure to firm's performance.

\section{Hausman Test of the variables}

The Hausman Test is applied to analyze the heteroskedasticity problem within the data set. 
Table 4: The Hausman Test of the variables

\begin{tabular}{|c|c|c|c|c|}
\hline \multirow{2}{*}{$\begin{array}{c}\text { Estimation } \\
\text { results }\end{array}$} & \multicolumn{2}{|c|}{ Shariah Compliant Listed Companies } & \multicolumn{2}{c|}{$\begin{array}{c}\text { Non-Shariah Compliant Listed } \\
\text { Companies }\end{array}$} \\
\cline { 2 - 5 } & $C h i^{2}(4)$ & Prob>Chi & $C h i^{2}(4)$ & Prob $>\mathrm{Chi}^{2}$ \\
\hline ROA & 12.51 & $0.0284^{* * *}$ & 47.22 & $0.0000^{* * *}$ \\
\hline ROE & 8.82 & 0.1164 & 11.36 & $0.0446^{* * *}$ \\
\hline MTBV & NA & NA & NA & NA \\
\hline
\end{tabular}

Note: Asterisks (***) and (**) AND (*) indicates significant at 1\%, 5\%, 10\% respectively.

As illustrated, the model for Shariah Compliant Listed Companies mostly are insignificant and fails to meet the asymptotic assumption of the Hausman Fixed Test for ROA and ROE, which means that there is heteroskedasticity problem within the dataset. The null hypothesis cannnot be rejected $\left(H_{0}\right.$ : Random effect is better) and the differences between fixed and random effect coefficient are not systematic.The result signified that the coefficient for random model is efficient but not for fixed model for ROA and ROE in Shariah complaint company. Therefore, researcher had to turn to random regression method as a

remedy to heteroskedasticity. Meanwhile, the coefficient for fixed model is efficient for ROA and ROE in Non-Shariah complaint company data set, suggesting that the null hypothesis can be be rejected ( $H_{0}$ : fixed effect is better). Hence, researcher had to turn to fixed regression method for ROA in Non-Shariahcomplaint company as a remedy to heteroskedasticity.

\section{Estimation Result}

Table 5: Estimation Result of the Variables

\begin{tabular}{|c|c|c|c|c|c|c|}
\hline \multicolumn{4}{|c|}{ Shariah Compliant Listed Companies } & \multicolumn{3}{|c|}{$\begin{array}{c}\text { Non-Shariah Compliant Listed } \\
\text { Companies }\end{array}$} \\
\hline \multirow{3}{*}{$\begin{array}{l}\text { Estimation } \\
\text { results }\end{array}$} & ROA & ROE & MTBV & ROA & ROE & MTBV \\
\hline & $\begin{array}{l}\text { Fixed- } \\
\text { Effects }\end{array}$ & $\begin{array}{l}\text { Random- } \\
\text { Effects }\end{array}$ & $\begin{array}{c}\text { Pooled } \\
\text { Regression }\end{array}$ & $\begin{array}{l}\text { Fixed- } \\
\text { Effects }\end{array}$ & $\begin{array}{l}\text { Fixed- } \\
\text { Effects }\end{array}$ & $\begin{array}{c}\text { Pooled } \\
\text { Regression }\end{array}$ \\
\hline & $\begin{array}{c}\text { Coefficient } \\
\text { t-statistic } \\
\text { p-value }\end{array}$ & $\begin{array}{c}\text { Coefficient } \\
\text { t-statistic } \\
\text { p-value }\end{array}$ & $\begin{array}{c}\text { Coefficient } \\
\text { t-statistic } \\
\text { p-value }\end{array}$ & $\begin{array}{c}\text { Coefficient } \\
\text { t-statistic } \\
\text { p-value }\end{array}$ & $\begin{array}{c}\text { Coefficient } \\
\text { t-statistic } \\
\text { p-value }\end{array}$ & $\begin{array}{c}\text { Coefficient } \\
\text { t-statistic } \\
\text { p-value }\end{array}$ \\
\hline STD & $\begin{array}{c}0.5326 \\
0.55 \\
(0.585)\end{array}$ & $\begin{array}{c}0.1483 \\
0.19 \\
(0.848)\end{array}$ & $\begin{array}{c}-3.6382 \\
-2.08 \\
(0.049)^{* * *}\end{array}$ & $\begin{array}{c}-0.1957 \\
-0.57 \\
(0.568)\end{array}$ & $\begin{array}{c}-0.4521 \\
-1.28 \\
(0.203)\end{array}$ & $\begin{array}{c}-0.1348 \\
-0.24 \\
(0.813)\end{array}$ \\
\hline LTD & $\begin{array}{c}0.2018 \\
1.05 \\
(0.297)\end{array}$ & $\begin{array}{c}0.0390 \\
0.30 \\
(0.761)\end{array}$ & $\begin{array}{c}-0.6606 \\
-2.74 \\
(0.012)^{* *}\end{array}$ & $\begin{array}{c}-0.1461 \\
-1.15 \\
(0.253)\end{array}$ & $\begin{array}{c}-0.3501 \\
-2.68 \\
(0.009)^{* * *}\end{array}$ & $\begin{array}{c}-0.1297 \\
-0.37 \\
(0.716)\end{array}$ \\
\hline TD & $\begin{array}{c}-0.8475 \\
-0.71 \\
(0.481)\end{array}$ & $\begin{array}{c}-0.0698 \\
-0.08 \\
(0.939)\end{array}$ & $\begin{array}{c}3.7687 \\
1.51 \\
(0.144)\end{array}$ & $\begin{array}{c}0.5349 \\
1.24 \\
(0.219)\end{array}$ & $\begin{array}{c}1.3331 \\
3.00 \\
(0.004)^{* * *}\end{array}$ & $\begin{array}{c}0.0306 \\
0.03 \\
(0.974)\end{array}$ \\
\hline SIZE & $\begin{array}{c}0.2291 \\
0.54 \\
(0.594)\end{array}$ & $\begin{array}{c}0.2304 \\
1.30 \\
(0.193)\end{array}$ & $\begin{array}{c}0.2088 \\
0.87 \\
(0.396)\end{array}$ & $\begin{array}{c}0.5991 \\
3.18 \\
(0.002)^{* * *}\end{array}$ & $\begin{array}{c}0.4981 \\
2.57 \\
(0.013)^{* *}\end{array}$ & $\begin{array}{c}-0.0226 \\
-0.19 \\
(0.850)\end{array}$ \\
\hline GROWTH & $\begin{array}{c}0.0486 \\
-0.42 \\
(0.673)\end{array}$ & $\begin{array}{c}0.0782 \\
0.81 \\
(0.415)\end{array}$ & $\begin{array}{c}0.0231 \\
0.10 \\
(0.919)\end{array}$ & $\begin{array}{c}-0.0120 \\
-0.22 \\
(0.825)\end{array}$ & $\begin{array}{c}-0.0053 \\
-0.10 \\
(0.924)\end{array}$ & $\begin{array}{c}-0.3098 \\
-0.98 \\
(0.330)\end{array}$ \\
\hline R-squared & 0.0337 & 0.0924 & 0.3315 & 0.1869 & 0.2513 & 0.0274 \\
\hline $\begin{array}{l}\text { Adjusted R- } \\
\text { Squared }\end{array}$ & 0.0008 & 0.0473 & 0.1861 & 0.0003 & 0.1243 & NA \\
\hline F-Stat & NA & NA & 2.28 & 2.99 & 4.36 & 0.42 \\
\hline Wald $\left(C h i^{2}\right)$ & 0.34 & 4.71 & NA & NA & NA & NA \\
\hline Prob (F-stat) & 0.8851 & 0.4529 & $0.0808 *$ & $0.0173 * *$ & $0.0017 * *$ & 0.8324 \\
\hline
\end{tabular}

Note: Asterisks (***) and (**) AND (*) indicates significant at 1\%, 5\%, $10 \%$ respectively and NA- Not Applicable 
The estimation result for this study illustrated that debt ratio (STD, and LTD) does given an impact to Shariah compliant listed company's performance at MTBV but does not contribute any impact toward ROA and ROE. This is also clear since $R^{2}$ for all independent variable are too weak to explain the dependent variables. Conversely, diverse result found for Non-Shariah compliant listed company data set. The result indicated that debt ratio does not given an impact to the company's performance toward MTBV, suggesting that debt ratio, size and growth does not really explain the MTBV of the Non-Shariah compliant listed company in Malaysia. However, overall it does contribute to performance through ROA and ROE. Therefore, this result has already answered the first objective of this research, which is to investigate whether debt ratios do influence the performance of Shariah and Non-Shariah compliant listed company in Malaysia, or not.

As to discover more on the important keys measures of capital structure to company's performance and their practices for both Shariah and Non- Shariah compliant listed company in Malaysia, therefore brief discussion are made by the researcher as follow;

As seen in the table 13, there is insignificant relationship betweendebt ratio (STD,LTD and TD)with ROA and ROE in Shariah compliant listed company data set , suggesting debt ratio does not give any impact to the Shariah compliant listed companies' performance based on ROA and ROE. Shariah compliant listed companies in this sample are probably confronting with default risk and compliance risk if their having higher loan. However, estimation result shows that STD and LTD does influence the company's performance toward MTBV with inverse relationship in the Shariah compliant listed companies as $\mathrm{Xu}$ Lixin supports the same finding. In addition, the coefficient value for STD with MTBV (-3.6382) are the strongest independent variables which influence the MTBV and followed by LTD. According to Cohen (1988), the correlation coefficient above 0.5 to 1.0 is considered strong or large between independent and dependent variable. This explained that one unit increase of STD and LTD would result in 3.6382 and 0.6606 unit decrease in MTBV respectively. From this result in can be concluded that the nature of construction business is normally used debt from banks for their working capital. However, working capital is difficult to raise the company's value, especially in the case of company mismanagement and as not being truly compliant. This indicated that Shariah compliant construction companies should strengthen corporate management of active use of short-term debt to the company benefits to enhance the company's market value as being Shariah compliant company. This result also relevant with the principle of Shariah compliant company which must not excessively involve in debt and expected to be less riskier and more stable. Therefore, due to the implication of MTBV and for being Shariah based company, Shariah compliant construction company must convince their investor by complying with the Shariah value and principle as they may look market value greater than the book value and values them far more than what they are stated as being worth from an accounting standpoint.

While, the analysis result point out that size and growth does not give any impact to Shariah compliant construction companies based on ROA, ROE, and MTBV which suggesting that size and growth of Shariah compliant listed companies does not influence the preference on the capital structure of their company. This is probably because since size and growth are often used as an indicator to stability of the company while in this study Shariah compliance construction listed companies are mostly big firm as apparently supported by mean value in the previous descriptive analysis. Therefore, benefit of the unique features of being Shariah Compliant makes them not highly leverage, meaning they are not risky, more stable and resilient.

On the other hand, the estimation result shows that debt ratio (STD, LTD and TD) also does not give any impact toward Non-Shariah compliant listed companies based on ROA. It is found that STD is insignificant negatively based on ROE (Ebaid, 2009; Zeitun and Tian (2007). However, in another study, Abor (2007) found opposite finding, which is positive relationship between STD with ROA and ROE in small and medium enterprises (SMEs) because of the nature of industry in which they are small operating and low level of interest rates. However, in this case, the study focus on the construction Company, which is big, and asset intensive companies, therefore they will not really depend on STD in boosting their company's performance. Nevertheless, there is significant negative relationship between LTD and TD with ROE, suggesting any increase in LTD and TD will decrease the company's performance in return on equity;however, it is not significant toward ROA and MTBV. The results are consistent with Wang (2013), Yadav (2012) and Ebaid (2009). The empirical tests indicate performance by using accounting measures of financial performance especially LTD and TD affect negatively on company's performance since the natures of Non-Shariah Compliant listed companies are different which they may have to increase their debt in order to convince the investor and have no restriction to do so. Moreover, company with more debt are said to have optimal capital structure and they have the ability to diversify risk. In general, a negative relationship between accounting measure of capital structure shows that capital structure has different material effect on company's performance and indicates that the agency issues may lead companies to use higher than appropriate levels of debt in their capital structure, which may negatively affect the company's performance.

Non-Shariah compliant listed company's analysis indicated that there is positively significant relationship between SIZE with ROA and ROE, which explains the larger the company, will increase the return on asset and return on equity. This result is parallel with Wang (2013), Yadav (2012 and Ebaid (2009) study. Besides, it is consistent with the Trade-Off Theory that suggests the larger companies tend to borrow more money due to their ability to diversify risk and maximum use of debt generates tax saving on interest payments, which play an important role in improving company's performance (Wang, 2013; Yadav, 2012 and Rahim, 2013). As the matter of fact, this is also relevant with the statistical data show in the descriptive analysis that Construction Company in this sample mostly big firm.

Estimation results also shows that there is insignificantly positive relation between independent variable (Growth) with ROA, ROE, and MTBV for Shariah and Non-Shariah compliant listed companies which 
explained that this independent variable can't really explain the dependent variable.

As a whole, the analysis shows a difference capital structure practices between Shariah and Non-Shariah compliant listed companies. This is cause by the different underlying value and principle practiced by both groups. Unlike Non-Shariah compliant listed companies, Shariah compliance listed companies does not involve with interest of debt in order to generate tax saving on interest payment since Shariah compliance companies will involve Islamic financing more focus on profit and risk sharing. Any participation in prohibited activity in Islamic principles is not allowed and it will be calculated according to ActivityBased Benchmark. Moreover, Shariah compliance companies are bind up with Islamic value and objective of Shariah (Maqasid Shariah; religion, life, intellect, lineage and property). Therefore, any activity, which violates the perseverance of this Maqasid Shariah, is considered ruthless (zulm).According to Asim (2010), debt financing is unjust to the poor and this supported by Nazrol Kamil (2005) that debt has many bad implication on society and prompt to speculation, which would lead to instability to the overall economy.

\section{Conclusion}

This study examines the impact of firm leverage toward performance of 70 construction Shariah and non Shariah compliance companies listed on the Main Board of Bursa Malaysia from year 2008 until 2012. In summary, the results in this study illustrates that Shariah compliant listed companies, only STD and LTD will have an impact towards the company's performance based on MTBV. It indicated significant negative relationship with MTBV as reflect to the nature business of being Shariah compliance. While, NOnShariah compliant listed companies explicit a different pattern and capital structure behavior in boosting their performance. The estimation result shows that size have positively significant relationship with ROA and ROE, while LTD and TD indicated significant relationship towards ROE. However, it seems the MTBV does not have any impact toward non-Shariah compliant listed company'sperformance in this sample.

Basically, the independent variables in this data set (STD, LTD, TD, SIZE and GROWTH) has not really explain the dependent variable (ROA and ROE) in the case of Shariah compliant listed companies as shown in the results of $R^{2}$ and probability. However, lower in $R^{2}$ does not mean it is bad. Since $R^{2}$ describes the unique variance explained by each variable therefore, even small uniqueness of the data is worth to study. This is also suggesting that there might be other variables, which can best explain the impact of capital structure towards Shariah compliant company's performance.

It is interesting to note that the analysis of this study shows a difference firm leverage practices between Shariah and Non-Shariah compliant listed companies. However, the researcher is not surprised with this outcome of this study because it is back to the basis for being shariah compliant which have different underlying value and principle to practice compared to not being compliance. Unlike NonShariah compliant listed companies, Shariah compliance listed companies does not involve with interest of debt in order to generate tax saving on interest payment since
Shariah compliance companies will involve Islamic financing more focus on profit and risk sharing.

For future researcher, it is proposed to extent the research period to ensure there are no biases in drawing conclusion and by covering a longer period; the study will be more meaningful in explaining the dependent variables. Besides, to understand more on the capital structure for Shariah compliant listed companies, therefore, it is suggested to future researcher to identify other independent variables of capital structure which may affect the shariah compliance company's performance such as equity ratio since the data of this study shows that shariah compliance company issued more on equity rather than debt.

\section{REFERENCES}

Abor, J., \& Biekpe, N. (2009). How do we explain the capital structure of SME in Sub-Saharan Africa? Evidence from Ghana.Journal of EconomicStudies, 36(1), 83-97.

Ahmad, Z, M.A. Abdullah, and S. Roslan. (2012). Capital Structure Effect on Firms Performance: Focusing on Consumers and Industrials Sectors on Malaysian Firms. International Review of Business Research Papers, 8(5), 137 - 155.

Asim, E. F. (2010). Islamic Finance: Debt versus Equity Financing in the Light of Maqasid. MPRA, Paper No. 20722.

Bar clay, M. J., and Smith, C. W. (1995), “The Maturity Structure of Corporate Debt", Journal of Finance 50, 609-32.

Chen, G., Firth, M.; and W.W Zhang. (2008). The efficiency and profitability effects of China's modern enterprise restructuring programme. Asian Review of Accounting, 16(1),74-91.

Coleman, A. K. (2007). The impact of capital structure on the performance of microfinance institutions. The Journal of Risk Finance, 8(1), 56-71.

Cohen, J. (1988). Statistical Power Analysis for the Behavioral Sciences. Erlbaum, Hillsdale, NJ.

Fitriya. (2012). The impact of islamic debt on firm's performance. University of waikato.

Jermias, J. (2008). The relative influence of competitive intensity and business strategy on the relationship between financial leverage and performance.British, 40, 71-86.

Kinsman, M. and Newman, J. (1999). Debt Level and Firm Performance: An Empirical Evaluation.Paper presented at 28th Annual Meeting of the Western Decision Science Institute, 1999, Puerto Vallarta, Mexico. 
Kamil, N. K. (2007). Islamic Banking and Finance Slides.

Malaysia: International Islamic University

Ibrahim El-Sayed Ebaid. (2009). The impact of capitalstructure choice on firm performance: Empirical evidence from Egypt, Journal of Risk Finance, $10(5), 477-487$.

Mohammed S Al-Dohaiman. (2008). Capital Structure in Saudi Arabian Listed and Unlisted Companies.A thesis submitted for the degree of Doctor of Philosophy, University of Stirling Scotland.

Muritala, T. A. (2012). An Empirical Analysis of Capital Structure on Firms' Performance in Nigeria. International Journal of Advances in Management and Economics, 1(5) , 116-124.

Myers, S. (1977), Determinants of corporate borrowings, Journal of Financial Economics, 5, 147-175.

Ogebe, P., Ogebe, J. and Alewi, K. (2013).The Impact of Capital Structure on Firms' Performance in Nigeria.Munich Personal RePEcArchiv (MPRA).

Rahim, N. A. (2013). Theoritical Investigation on Determinant of Government_linked Companies Capital Structure. Journal of Accounting, Finance and Economics , 3(2), 72-85.

Rajan, R. a. (1995). what do we know about capital structure? some evidence from internatioanl data. Journal of Finance , 50 (5), 1431-60.

Tian, R. Z. (2007). Capital Structure and Corporate Performance: Evidence From Jordan. The Australian Accounting Business \& Finance Journal, 1(4), 40.

Wang, N. A. (2013). The Impact of capital Structure on Performance. International Journal of Commerce and Management, 354-368.

Xu Lixin, C. L. The Relationship Between Debt Financing and Market Value of Company: Empirical Study of Listed Real Estate Company of China. Proceedings of the 7th International Conference on Innovation \& Management

Yadav, M. S. (2012). Capital Structure and Firm Performance: Evidence from Malaysian Listed Companies. International Congress on Interdisciplinary Business and Social Science. 